\title{
GOSPODARKA ODPADAMI PROMIENIOTWÓRCZYMI
}

\begin{abstract}
W artykule omówiono pojęcia związane ze składowaniem, transportowaniem i unieszkodliwianiem odpadów promieniotwórczych. Scharakteryzowano gospodarkę tymi odpadami w kilku krajach oraz warunki pracy Zakładu Unieszkodliwiania Odpadów Promieniotwórczych.
\end{abstract}

Słowa kluczowe: składowanie, transportowanie, unieszkodliwianie odpadów promieniotwórczych

\section{Wprowadzenie}

Odpady promieniotwórcze powstają podczas wytwarzania, przechowywania, składowania, stosowania materiałów jądrowych i źródeł promieniotwórczych oraz eksploatacji i likwidacji obiektów jądrowych. Są to odpady stałe, ciekłe lub gazowe, zawierające substancje promieniotwórcze lub skażone tymi substancjami.

Klasyfikację odpadów niebezpiecznych przeprowadza się według listy stworzonej przez ministra ochrony środowiska, zasobów naturalnych i leśnictwa w porozumieniu z prezesem GUS. W innych krajach Unii Europejskiej o przyporządkowaniu danego odpadu do danej kategorii decydują wyniki analiz i pomiarów.

Odpady promieniotwórcze są kwalifikowane ze względu na poziom aktywności lub moc dawki na powierzchni. Zgodnie z tym kryterium wyróżnia się następujące kategorie odpadów:

- niskoaktywne,

- średnioaktywne,

- wysokoaktywne.

Kategorie te mogą być podzielone na podkategorie, ze względu na okres połowicznego rozpadu zawartych $\mathrm{w}$ odpadach izotopów promieniotwórczych lub wydzielaną moc cieplną. Są to:

- odpady krótkożyciowe,

- odpady długożyciowe. 
Dodatkową kategorię odpadów promieniotwórczych tworzą wycofane z użytkowania zamknięte źródła promieniotwórcze.

Kwalifikacji odpadów promieniotwórczych dokonuje kierownik jednostki organizacyjnej, na terenie której znajdują się odpady, bądź prezes agencji w przypadku rozbieżności między kwalifikacją dokonaną przez kierownika jednostki organizacyjnej, na terenie której znajdują się odpady, a kwalifikacją dokonaną przez kierownika jednostki organizacyjnej przyjmującej odpady lub stwierdzenia nieprawidłowości w kwalifikacji dokonanej przez kierownika jednostki organizacyjnej, na terenie której znajdują się odpady.

Do źródeł pochodzenia odpadów promieniotwórczych można zaliczyć:

- kopalnie rud uranu i zakłady przerobu tych rud,

- produkcję paliwa reaktorowego oraz przerób paliwa wypalonego,

- eksploatacje reaktorów energetycznych i badawczych,

- likwidacje reaktorów jądrowych,

- stosowanie izotopów promieniotwórczych w medycynie, rolnictwie, przemyśle i badaniach naukowych.

Właściwe gospodarowanie odpadami promieniotwórczymi skutecznie chroni człowieka i środowisko naturalne przed szkodliwym wpływem emitowanego przez nie promieniowania jonizującego. Podczas składowania, utylizacji i transportu odpadów obowiązują określone zasady dotyczące:

- minimalizowania ilości powstających odpadów,

- odpowiedniego segregowania odpadów (oddzielnie ciekłe, oddzielnie nadające się do rozdrobnienia, prasowania, spalania itd.),

- zmniejszania objętości odpadów (prasowanie, odparowanie itp.),

- zestalania i pakowania odpadów, tak aby były chemicznie i fizycznie stabilne,

- składowania odpadów w miejscach o właściwej strukturze geologicznej i stosowania wszystkich możliwych technologii oraz barier, które skutecznie izolują odpady od człowieka i środowiska.

\section{Składowanie odpadów promieniotwórczych}

Odpady promieniotwórcze i wypalone paliwo jądrowe przechowuje się w warunkach umożliwiających ich segregację oraz zapewniających ochronę ludzi i środowiska. Odpady promieniotwórcze można składować wyłącznie w stanie stałym, w opakowaniach zapewniających bezpieczeństwo ludziom i środowisku pod względem ochrony radiologicznej, z zapewnieniem odprowadzania ciepła i niedopuszczenia do powstania masy krytycznej oraz prowadzenia stałej kontroli tych czynników w okresie składowania, a także po zamknięciu składowiska.

Odpady przechowuje się w obiekcie lub pomieszczeniu (magazyn odpadów promieniotwórczych) wyposażonym w urządzenia do wentylacji mechanicznej 
lub grawitacyjnej oraz do oczyszczania powietrza usuwanego z tego pomieszczenia, zaliczonym zgodnie z przepisami budowlanymi co najmniej do klasy B odporności pożarowej i zabezpieczonym przed zalaniem wodą.

Wejście do magazynu odpadów promieniotwórczych, jak również opakowania do przechowywania średnio- i wysokoaktywnych odpadów promieniotwórczych oznacza się tablicą informacyjną. Na tablicy zostają umieszczone informacje o zawartości oraz temperaturze, której nie mogą przekroczyć przechowywane odpady, i temperaturze, której nie może przekroczyć opakowanie $\mathrm{z}$ tym odpadem.

Ściany zewnętrzne i stropy magazynu odpadów promieniotwórczych lub zastosowane osłony powinny mieć taką konstrukcję, która będzie zapobiegać otrzymaniu przez osoby pracujące $\mathrm{w}$ magazynie rocznej dawki skutecznej (efektywnej) od wszystkich dróg narażenia przekraczającej wartość $0,1 \mathrm{mSv}$. Magazyn odpadów promieniotwórczych wyposaża się więc w sprzęt dozymetryczny, odpowiedni ze względu na rodzaj emitowanego promieniowania jonizującego, w stałe lub ruchome osłony przed promieniowaniem, środki ochrony indywidualnej przed skażeniami promieniotwórczymi i napromieniowaniem, a także w instalację wodną i kanalizacyjną. W obiektach nieposiadających specjalnej kanalizacji ciekłe odpady promieniotwórcze można przechowywać w pojemnikach lub zbiornikach ze stali nierdzewnej lub z tworzyw sztucznych, których pojemność nie przekracza $100 \mathrm{dm}^{3}$, oraz w pojemnikach szklanych lub ceramicznych zabezpieczonych przed uszkodzeniami mechanicznymi, których pojemność nie przekracza $25 \mathrm{dm}^{3}$.

W magazynie, w którym są przechowywane odpady promieniotwórcze niegenerujące gazów, zapewnia się wentylację zapobiegająca powstawaniu zjawiska roszenia na powierzchni opakowań oraz na ścianach magazynu. Odpady promieniotwórcze wytwarzające gazy lub mogące spowodować skażenie promieniotwórcze powietrza są przechowywane w magazynie wyposażonym $\mathrm{w}$ wentylację mechaniczna, umożliwiającą zmniejszenie stężenia powstałych gazów lub skażeń do poziomu, który można pominąć z punktu widzenia ochrony radiologicznej.

Oddzielnie od pozostałych ciekłych odpadów promieniotwórczych w odrębnych zbiornikach lub pojemnikach przechowuje się ciekłe odpady promieniotwórcze zawierające izotopy alfapromieniotwórcze i izotopy, których okres połowicznego rozpadu nie przekracza $65 \mathrm{dni}$. Ciekłe odpady promieniotwórcze zawierające organiczne rozpuszczalniki, ekstrahenty, oleje lub detergeny o stężeniu przekraczającym $10 \mathrm{mg} / \mathrm{dm}^{3}$ czy też substancje kompleksotwórcze o stężeniu przekraczającym $10 \mathrm{mg} / \mathrm{dm}^{3}$, substancje rozpuszczone i osady o zawartości przekraczającej $10 \mathrm{~g} / \mathrm{dm}^{3} \mathrm{w}$ przeliczeniu na suchą pozostałość przechowuje się oddzielnie od siebie oraz od odpadów zawierających izotopy.

Wszelkie opakowania przeznaczone do przechowywania odpadów promieniotwórczych dostosowuje się do stanu skupienia i właściwości fizykochemicznych odpadów promieniotwórczych. Materiał tych opakowań nie może wcho- 
dzić w reakcje chemiczne z odpadami promieniotwórczymi. W związku z tym stałe odpady promieniotwórcze przechowuje się w pojemnikach stalowych, betonowych, $\mathrm{z}$ tworzyw sztucznych oraz $\mathrm{w}$ bębnach lub w workach foliowych (tylko odpady niskoaktywne) $\mathrm{z}$ tworzyw sztucznych o grubości powyżej $0,5 \mathrm{~mm}$. Ciekłe odpady promieniotwórcze przechowuje się $\mathrm{w}$ zbiornikach stalowych pokrytych wewnątrz powłoką chemoodporna, zbiornikach betonowych uszczelnionych od wewnątrz i pokrytych powłoką chemoodporną lub zbiornikach z tworzyw sztucznych laminowanych.

Odbiorem, transportem, przetwarzaniem i składowaniem odpadów powstających u wszystkich użytkowników materiałów promieniotwórczych w Polsce zajmuje się Zakład Unieszkodliwiania Odpadów Promieniotwórczych (ZUOP). Jest to państwowe przedsiębiorstwo użyteczności publicznej $\mathrm{z}$ siedzibą w Otwocku-Świerku, powołane do wykonywania działalności w zakresie postępowania z odpadami promieniotwórczymi i wypalonym paliwem jądrowym, a przede wszystkim do zapewnienia stałej możliwości składowania odpadów promieniotwórczych i wypalonego paliwa jądrowego. Zakład może również wykonywać działalność w zakresie postępowania z odpadami niebezpiecznymi.

Nadzór nad zakładem oraz funkcję organu założycielskiego sprawuje minister właściwy do spraw gospodarki. Przeprowadza on kontrolę i dokonuje corocznej oceny działalności zakładu, którą przedstawia prezesowi rady ministrów do dnia 30 marca roku następnego.

Miejscem składowania powstających w Polsce odpadów promieniotwórczych jest Krajowe Składowisko Odpadów Promieniotwórczych w Różanie. Składowiska odpadów promieniotwórczych dzieli się na powierzchniowe i głębokie. Krajowe składowiska odpadów promieniotwórczych zostają uznane $\mathrm{w}$ drodze decyzji prezesa agencji, przy czym składowiska te muszą przez co najmniej 11 miesięcy w roku spełniać warunki przyjmowania odpadów promieniotwórczych w celu ich składowania i przechowywania.

KSOP jest typem składowiska powierzchniowego zlokalizowanego na terenie byłego fortu wojskowego. Składowisko to jest przeznaczone do składowania krótkożyciowych odpadów nisko- i średnioaktywnych oraz okresowego przechowywania odpadów długożyciowych. W KSOP mogą być składowane odpady wyłącznie w postaci stałej lub zestalonej. Powinny one spełniać następujące warunki:

- nie powinny wydalać produktów gazowych (wyjątek stanowią odpady zawierające izotopy rozpadające się do produktów gazowych, np. Ra226),

- nie powinny zawierać substancji wybuchowych, łatwopalnych lub wykazujących się powinowactwem chemicznym w stosunku do barier ochronnych,

- nie powinny zawierać cieczy niezwiązanej powyżej 1\% całkowitej masy odpadów, 
- ługowalność z produktów zestalania odpadów niskoaktywnych nie powinna być większa niż $10^{2} \mathrm{~g} \cdot \mathrm{cm}^{-2} \cdot \mathrm{d}^{-1}$, a dla średnioaktywnych $10^{-3} \mathrm{~g} \cdot \mathrm{cm}^{-2} \cdot \mathrm{d}^{-1}$

- pojemniki z odpadami powinny być szczelnie zamknięte w sposób zabezpieczający przed ich wydostaniem się na zewnątrz.

Stałe i zestalone odpady są umieszczane w betonowych obiektach tego fortu, których grubość ścian i stropów wynosi 1,2-1,5 m. Miejscem składowania odpadów krótkożyciowych nisko- i średnioaktywnych jest także część adaptowanej do tego celu suchej fosy. Opakowane odpady są umieszczane warstwami $\mathrm{w}$ fosie i zalewane betonem $\mathrm{z}$ dodatkiem bentonitu, który, ze względu na właściwości sorpcyjne, wspomaga skuteczność izolacji odpadów. Ostatnie, najwyżej znajdujące się odpady są pokrywane $40 \mathrm{~cm}$ warstwą betonu i zaimpregnowane mieszanką bitumiczną ograniczającą możliwości infiltracji wód opadowych do wnętrza tej konstrukcji.

Skuteczność stosowanych zabezpieczeń jest systematycznie sprawdzana przez kontrolę:

- narażenia radiologicznego pracowników na podstawie pomiarów indywidualnych,

- radioaktywności podstawowych elementów środowiska naturalnego (powietrze, woda, gleba, roślinność),

- poziomu promieniowania na terenie i w otoczeniu składowiska.

W blisko czterdziestoletnim okresie eksploatacji składowiska zgromadzonych zostało ok. $3300 \mathrm{~m}^{3}$ odpadów o sumarycznej aktywności $33,78 \mathrm{TBq}$. ZUOP posiada Zezwolenie z dnia 18 listopada 1999 r. na eksploatację Krajowego Składowiska Odpadów Promieniotwórczych w Różanie, wydane przez prezesa Państwowej Agencji Atomistyki.

\section{Transport}

Przygotowując do transportu i transportując odpady promieniotwórcze, należy uwzględnić zagrożenia, jakie mogą stwarzać ich właściwości fizykochemiczne, a także spełnić wymagania i warunki obowiązujące w transporcie materiałów niebezpiecznych [1]. Aby zmniejszyć ryzyko podczas przewozu, Rada Społeczno-Ekonomiczna ONZ upoważniła Międzynarodową Agencję Energii Atomowej (MAEA) do przygotowania i zarekomendowania przepisów i standardów dotyczących bezpiecznego transportowania materiałów promieniotwórczych.

Materiały promieniotwórcze są przewożone w różnych opakowaniach zapewniających bezpieczeństwo przesyłki w czasie transportu, zarówno dla przewoźników, jak i środowiska naturalnego. 
Rodzaj opakowania, w jakim przewozi się materiały promieniotwórcze, zależy od gatunku tego materiału, jego objętości, ilości, postaci fizycznej i aktywności. W związku z tym poszczególne typy opakowań są konstruowane pod względem odpowiednich parametrów wytrzymałościowych i materiałowych. Opakowania typu A muszą zapewniać szczelność i osłonę ładunku w przypadku zaistnienia mniejszych wypadków transportowych. Są one również poddawane testom wytrzymałościowym, ale nie tak surowym, jak opakowania typu B. Muszą być odporne na deszcz i ewentualny upadek z pojazdu. Zakłada się jednak, że opakowanie takie może zostać uszkodzone w czasie transportu, a jego zawartość wydostać się na zewnątrz. Przepisy określają więc maksymalną ilość substancji promieniotwórczej, jaka może być przewożona w tego typu opakowaniu.

Opakowania typu B mają podwyższoną wytrzymałość mechaniczną i termiczną, ponieważ muszą zapewnić szczelność i osłonę ładunku nawet podczas poważnych wypadków transportowych. Używane są do przewozu najbardziej radioaktywnych materiałów (wypalone paliwo, wysokoaktywne odpady promieniotwórcze). Są one poddawane surowym testom mechanicznym, termicznym i zanurzeniowym. Muszą posiadać autoryzację, czyli certyfikat wydany przez właściwe organy dozoru jądrowego i ochrony radiologicznej kraju.

Opakowania przemysłowe (IP) służą do transportu materiałów o niskiej aktywności lub przedmiotów skażonych powierzchniowo. Zawarta w nich ilość materiału aktywnego stanowi - w sytuacjach awaryjnych - znikome zagrożenie dla ludzi i środowiska. Ten typ opakowań jest również poddawany niektórym testom wytrzymałościowym. Opakowań tego typu używa się przede wszystkim do transportu rud radioaktywnych i niskoaktywnych odpadów promieniotwórczych.

Opakowania tzw. wyłączone są używane do transportu maleńkich ilości materiałów promieniotwórczych, np. radiofarmaceutków czy urządzeń, zawierających źródła promieniotwórcze o bardzo niskiej aktywności (izotopowe czujki dymu, przyrządy pomiarowe). Są to m.in. pudełka kartonowe, pojemniki z tworzyw sztucznych czy metalowe puszki. Przewóz takich przesyłek nie jest już tak rygorystycznie uwarunkowany. Nie muszą one posiadać np. nalepek ostrzegawczych, ale wewnątrz powinna się znajdować informacja o przewożonym materiale [2].

\section{Unieszkodliwianie odpadów promieniotwórczych}

Unieszkodliwianie odpadów promieniotwórczych powinno rozpoczynać się w miejscu ich powstawania. Polega ono na tworzeniu barier ochronnych zabezpieczających przed uwalnianiem się substancji promieniotwórczych w miejscu ich składowania i zapobiegających emisji do środowiska. Rozróżnia się dwie podstawowe grupy barier ochronnych: 
1) bariery naturalne - to warunki geologiczne i hydrogeologiczne terenu i złoża, na którym jest zlokalizowane składowisko odpadów; jakość tej bariery określają następujące czynniki:

- izolacja od wód opadowych, powierzchniowych i podziemnych (obecność zbiorników wodnych, kierunki i szybkość przepływu wód gruntowych, fluktuacja zwierciadła wód),

- właściwości złoża decydujące o szybkości migracji radionuklidów (przepuszczalność, właściwości sorpcyjne),

2) bariery sztuczne - to zabezpieczenia wykonane przez człowieka i tworzone na każdym etapie unieszkodliwiania odpadów; są to materiały o różnych właściwościach i konstrukcje spełniające podstawową funkcję eliminowania lub ograniczania:

- infiltracji wód gruntowych i opadowych do miejsc składowania odpadów promieniotwórczych,

- rozproszenia się i migracji substancji promieniotwórczych ze składowiska do otoczenia,

- ługowalności substancji promieniotwórczych z odpadów,

- niszczącego działania roślin i zwierząt.

Elementami sztucznych barier ochronnych sa:

- forma odpadów - postać fizyczno-chemiczna substancji promieniotwórczych zawartych w odpadach wraz z materiałem nieaktywnym,

- opakowanie - osłona, materiały izolacyjne,

- materiały wypełniające - wypełniają wolne przestrzenie w komorze składowania (pomiędzy opakowaniem i miejscem składowania, np. beton z kruszywem barytowym, mieszanina piasku i bentonitu),

- materiał i konstrukcja komór składowania,

- materiały izolacyjne - mogą być związane z konstrukcją komór składowania lub tworzyć oddzielne warstwy.

\section{Gospodarka odpadami promieniotwórczymi we Francji i na Ukrainie}

Francja, jako jeden z nielicznych krajów na świecie, zajmuje się przeróbką paliwa wypalonego. Działalność tego typu prowadzą dwa zakłady: w Marcoule na południu Francji (o zdolności produkcji 1000 ton/rok, uruchomiony już w 1958 r.) oraz w La Hague na północy w Normandii (o zdolności produkcji 1600 ton/rok, uruchomiony w 1967 r.). Przedsiębiorstwa te świadczą usługi również dla elektrowni spoza Francji, np. Niemiec, Szwajcarii, Japonii. Całością procesów wytwarzania i przeróbki paliwa jądrowego we Francji zajmuje się państwowe towarzystwo COGEMA (Compagnie Générale des Matieres Nucléaires). Problematyką odpadów promieniotwórczych zajmuje się natomiast insty- 
tucja pod nazwą ANDRA (1'Agence Nationale Pour le Traitement des Déchets Radioactifs) utworzona w 1979 r. która dysponuje dwoma składowiskami powierzchniowymi, tj. La Manche oraz L`Aube. Pierwsze - zlokalizowane w Pointe-du-Cotentin w pobliżu La Hague - to składowisko odpadów niskoi średnioaktywnych o powierzchni 12 ha i pojemności $535000 \mathrm{~m}^{3}$ uruchomione w 1969 r. Obecnie są prowadzone prace związane z zamknięciem tego składowiska. Drugie - zlokalizowane w Soulaines w pobliżu Aube w Szampanii - to składowisko odpadów niskoaktywnych o powierzchni 95 ha i pojemności $1 \mathrm{mln} \mathrm{m}{ }^{3}$, uruchomione w $1992 \mathrm{r}$. Należy podkreślić, że francuska energetyka jądrowa dąży do systematycznego obniżania wielkości odpadów promieniotwórczych z elektrowni jądrowych. O ile 10 lat temu roczna ilość odpadów wynosiła $350 \mathrm{~m}^{3}$ na jeden blok, o tyle obecnie jest ona 3-krotnie niższa i wynosi mniej niż $100 \mathrm{~m}^{3}$. W przeliczeniu na jednego mieszkańca rocznie energetyka jądrowa we Francji wytwarza $1 \mathrm{~kg}$ odpadów promieniotwórczych, z czego $10 \mathrm{~g}$ stanowią odpady wysokoaktywne (w nich jest zawarte $95 \%$ całkowitej promieniotwórczości). Przykładowo warto podać, że wielkość odpadów przemysłowych na jednego mieszkańca Francji wynosi $3000 \mathrm{~kg}$ rocznie, tak więc wielkość odpadów promieniotwórczych stanowi zaledwie $0,03 \%$ wielkości odpadów przemysłowych [3].

Ukraina każdego roku wytwarza ok. 265 ton zużytego paliwa jądrowego. Paliwo jądrowe początkowo jest gromadzone na terenie reaktorów, w których zostało wykorzystane. Jeszcze niedawno było ono przekazywane do Rosji w celu utylizacji bądź powtórnego przerobu, jednak ze względu na warunki ekonomiczne zaprzestano wywozu zużytych materiałów. Obecnie na terenie Ukrainy znajduje się sześć miejsc przechowywania wysoko- i średnioaktywnych odpadów (włączając w to strefę wokół zniszczonej elektrowni w Czarnobylu). Problematyka odpadów radioaktywnych należy do obowiązków Ministerstwa Awarii Czarnobylskiej (obecnie części składowej Ministerstwa Sytuacji Nadzwyczajnych). W 1996 roku rząd uchwalił program zagospodarowania odpadów radioaktywnych do 2005 r. Nałożył obowiązek ewidencjonowania odpadów, regularnego kontrolowania składowisk odpadów i ich modernizacji. Program zakłada, że odpady będą przechowywane w basenach z wodą w miejscu wytworzenia przynajmniej do 2005 r. Do tego też roku miało być wyznaczone miejsce i wybudowane podziemne składowisko odpadów radioaktywnych [4].

\section{Gospodarka odpadami promieniotwórczymi w Japonii i Kanadzie}

Za regulację cyklu paliwowego w japońskiej energetyce jądrowej oraz za składowanie odpadów promieniotwórczych jest odpowiedzialne Ministerstwo Ekonomii Handlu i Przemysłu. Japonia posiada dobrze rozwinięty przemysł związany z cyklem paliwowym w energetyce jądrowej. Dysponuje własnymi zakładami wzbogacania uranu w Ningyo Toge, które są zarządzane przez JNC, 
oraz w Rokkasho, zarządzane przez prywatne konsorcjum Japan Nuclear Fuel Limited (JNFL). Zakłady przerobu wypalonego paliwa znajdują się w Tokaimura (JNC) oraz Rokkasho (JNFL). Część wypalonego paliwa z japońskich elektrowni jądrowych jest nadal przerabiana w Europie, we Francji lub w Wielkiej Brytanii. Na terenie Rokkasho znajduje się również centralne składowisko niskoaktywnych odpadów promieniotwórczych (o pojemności 200 tys. $\mathrm{m}^{3}$, co jest równoważne $1 \mathrm{mln}$ beczek 200 1), składowisko wypalonego paliwa jądrowego (obecnie znajduje się tam 779 ton paliwa $\mathrm{z}$ reaktorów typu BWR i PWR) oraz składowisko zestalonych odpadów promieniotwórczych powstałych z przeróbki wypalonego paliwa. Większość wypalonego paliwa znajduje się nadal w basenach przechowalnikowych na terenie elektrowni jądrowych [5].

Za przechowywanie odpadów promieniotwórczych w Kanadzie odpowiadają ich producenci, czyli właściciele i dyrektorzy zakładów. Po wypaleniu pręty paliwowe zdalnie przenoszone są do zbiorników (basenów) napełnionych wodą, zwanych Irradiated Bays Fuel (IBF), na czas ich ostygnięcia i znacznego zmniejszenia poziomu promieniowania. Baseny te o specjalnej konstrukcji i wzmocnieniach mają zabezpieczać przed wyciekami i skutkami ewentualnych trzęsień ziemi. Po około 7-10 latach temperatura elementów paliwowych spada wystarczająco, aby można je było przenieść do suchych zbiorników. Następnie są one zalewane specjalnym koncentratem i transportowane do miejsca składowania. Obecnie w Kanadzie odpady radioaktywne przechowywane są w następujących zakładach:

1. AECL (Chalk River Laboratories) są własnością Atomic Energy of Canada Limited i zlokalizowane w pobliżu Deep River w Ontario. Większość przechowywanych tu odpadów pochodzi z zamkniętej już elektrowni w Rolphton.

2. AECL (Whiteshell Laboratories) - położone w południowo-wschodnim Manitoba zostały założony przez AECL w $1960 \mathrm{r}$. Większość odpadów to wykorzystane paliwo z nieczynnego reaktora w Douglas Point oraz niestandardowe odpady z innych źródeł.

3. AECL (Douglas Point Waste Management Facility) - jest położone w Kincardine w Ontario. Przechowuje 22,256 zużytych prętów paliwowych (zakład zamknięto w $1986 \mathrm{r}$.).

4. Hydro-Québec - posiada i obsługuje Gentilly-2, reaktor jądrowy zlokalizowany blisko Trois-Rivieres w Québecu. Zużyte paliwo reaktora jest gromadzone przez minimum siedem lat w IBF, następnie przechowywane $\mathrm{w}$ jedenastu silosach wewnątrz nieczynnego budynku turbiny. Zgromadzono tu 3,213 prętów paliwowych.

5. New Brunswick Power - siłownia Point Lepreau położona $40 \mathrm{~km}$ na zachód od St. John, New Brunswick.

6. Ontario Power Generation - jest odpowiedzialne za paliwo zużyte przez reaktory w siłowniach w Pickering, Darlington i Bruce Power w Ontario. Początkowo jest ono przechowywane w IBF na terenie tych zakładów, a na- 
stępnie składowane w OPG w suchych zbiornikach, z których każdy mieści 384 zużyte pręty paliwowe. Zakład działa od $1996 \mathrm{r}$.

7. Bruce Power - obsługuje reaktor w Kincardine.

\section{Ochrona przed promieniowaniem jonizującym na przykładzie działalności Zakładu Unieszkodliwiania Odpadów Promieniotwórczych (ZUOP)}

Zakład Unieszkodliwiania Odpadów Promieniotwórczych jest jedyną w Polsce instytucją zajmującą się kompleksowo unieszkodliwianiem odpadów promieniotwórczych. Zakład wykonuje kompleks usług, poczynając od odbioru promieniotwórczych odpadów, poprzez ich transport, kończąc na utylizacji i składowaniu.

ZUOP stosuje nowoczesne technologie unieszkodliwiania odpadów promieniotwórczych, które pozwalają na uzyskanie wysokich współczynników redukcji objętości oraz na przygotowanie odpadów w sposób zapewniający bezpieczeństwo ludności i środowiska naturalnego w całym okresie ich składowania. Zakład dysponuje własnymi środkami transportu, umożliwiając przewóz odpadów promieniotwórczych. Odpady te mogą być transportowane w różnej postaci fizycznej, w opakowaniach i o różnych gabarytach.

Odpady, które trafiają do ZUOP, są utylizowane na jedynym w Polsce Krajowym Składowisku Odpadów Promieniotwórczych (KSOP) w Różanie. KSOP jest składowiskiem powierzchniowym zlokalizowanym na terenie byłego fortu wojskowego. Składowisko to przeznaczone jest do ostatecznego składowania krótkożyciowych odpadów nisko- i średnioaktywnych oraz do okresowego składowania odpadów długożyciowych.

Działalność ZUOP ma zasięg ogólnokrajowy o charakterze służby publicznej i obejmuje następujące zadania [5]:

- odbiór odpadów promieniotwórczych,

- transport odpadów,

- przetwarzanie i zestalanie odpadów,

- kontrola jakości odpadów kierowanych do składowania,

- przechowywanie i składowanie odpadów promieniotwórczych,

- dekontaminacja skażonych urządzeń, instalacji i obiektów,

- likwidacja skutków awarii radiologicznych.

Powstające odpady promieniotwórcze są przekazywane do ZUOP, gdzie podlegają segregacji, „schładzaniu” (okresowemu magazynowaniu mającemu na celu obniżenie aktywności odpadów, które następuje w wyniku rozpadu izotopów krótkożyciowych), a następnie przetwarzaniu. Proces przetwarzania ma na celu redukcję objętości odpadów oraz nadanie im formy dogodnej do dokony- 
wania dalszych operacji przeprowadzanych na nich, tj. bezpiecznego transportu i długotrwałego składowania.

Proces przetwarzania ciekłych odpadów promieniotwórczych odbywa się za pomocą metody sorpcji na mieszaninie syntetycznych sorbentów nieorganicznych, złożonej z węglanu baru i żelazocyjanku miedziowego. W wyniku oczyszczania otrzymuje się tzw. koncentrat promieniotwórczy, zawierający ok. 99\% początkowej aktywności ścieków, który podlega dalszemu przetwarzaniu.

Jako materiał wiążący stosuje się mieszaninę cementu portlandzkiego z cementem hutniczym $\mathrm{z}$ dodatkami stabilizującymi jednorodność otrzymanego produktu. Produkt ten jest następnie umieszczany w stalowych ocynkowanych bębnach, zamykany pokrywą i transportowany do składowiska odpadów.

Odpady stałe są przetwarzane $\mathrm{z}$ wykorzystaniem mechanicznych technik redukcji objętości. Odpady prasowalne, stanowiące ok. 45\% wszystkich odpadów stałych, są zgniatane w stalowych 200-litrowych bębnach w prasie hydraulicznej o nacisku 12 ton. W zależności od rodzaju prasowanych odpadów uzyskiwane wartości współczynników redukcji objętości wynoszą 1,5-3,0. W przypadku odpadów o większych gabarytach stosuje się fragmentację (cięcie) w celu optymalizacji transportu i warunków składowania. Sprasowane i pocięte odpady umieszcza się w stalowych bębnach, a następnie zalewa betonem. Po wypełnieniu bębna zamyka się go stalową pokrywą i w tej postaci transportuje do miejsca składowania.

Firma ZUOP zajmuje się również utylizacją źródeł radowych. Zatapia się je $\mathrm{w}$ ampułce szklanej i umieszcza w mosiężnej gilzie. Jest ona hermetycznie zamykana w zasobniku ze stali nierdzewnej, który jest wkładany do gniazda osłonowego. Ostatecznie pojemnik ten jest umieszczany w obudowie ze stali zwykłej i zalewany betonem. Po ułożeniu warstwy ziemi okrzemkowej na powierzchni pokrytego betonem pojemnika obudowa jest zamykana pokrywą.

Stosowane w ZUOP technologie utylizacji ulegają systematycznej modyfikacji i doskonaleniu, co jest związane z koniecznością dostosowania ich do coraz wyższych wymagań dotyczących jakości przetworzonych odpadów przeznaczonych do okresowego bądź ostatecznego składowania, a także rosnącymi wymaganiami w zakresie ochrony środowiska.

Polska nie miał problemu z unieszkodliwianiem odpadów promieniotwórczych, aż do 1958 r., kiedy to w Instytucie Badań Jądrowych w Świerku koło Otwocka został uruchomiony pierwszy w kraju badawczy reaktor jądrowy EWA. Wtedy to pojawił się problem z odpadami promieniotwórczymi. W Instytucie Badań Jądrowych nastapiło nagromadzenie się zużytych źródeł promieniotwórczych pochodzących z importu oraz odpadów powstałych podczas konfekcjonowania izotopów. Pojawiły się nowe rodzaje odpadów, tzn. koncentraty promieniotwórcze (zużyte jonity z układów oczyszczania wód obiegów chłodzenia reaktora, szlamy postrąceniowe będące wynikiem oczyszczania ścieków promieniotwórczych) wymagające dalszego oczyszczania. 
Trzy lata po uruchomieniu reaktora EWA w 1961 r. rozpoczęto eksploatację pierwszego w Centralnej Składnicy Odpadów Promieniotwórczych w Różanie. Wiązało się to z koniecznością opracowania i wdrożenia pełnej technologii unieszkodliwiania odpadów w formę dogodną do bezpiecznego transportu i długotrwałego składowania. Wymagało to również budowy nowych obiektów i instalacji unieszkodliwiania odpadów.

W początkowym okresie zagadnieniem unieszkodliwiania odpadów promieniotwórczych zajmowała się Centrala Odpadów Promieniotwórczych (COP) b. Instytutu Badań Jądrowych (IBJ), będąca w strukturze organizacyjnej instytutu gospodarstwem pomocniczym. W 1970 roku COP został przekształcony w Zakład Unieszkodliwiania Substancji Promieniotwórczych (ZUSP), po czym włączony do nowo utworzonego Ośrodka Reaktorów i Produkcji Izotopów (ORiPI) w Instytucie Energii Atomowej (IEA), powstałym w 1983 r. po likwidacji IBJ.

W 1988 roku, po wyodrębnieniu się ORiPI z IEA i utworzeniu Ośrodka Badawczo-Rozwojowego Izotopów, ZUSP znalazł się w strukturze Instytutu Energii Atomowej. Decyzją dyrektora IEA z dniem 1 stycznia 1994 r. został on przekształcony w Zakład Doświadczalny Unieszkodliwiania Odpadów Promieniotwórczych (ZDUOP) z rozszerzoną, w stosunku do innych zakładów instytutu, samodzielnością finansową. $Z$ dniem 1 stycznia 2002 r. ZDUOP IEA został przekształcony w przedsiębiorstwo państwowe użyteczności publicznej pn. Zakład Unieszkodliwiania Odpadów Promieniotwórczych.

Odkrycie promieniotwórczości z jednej strony umożliwiało pozytywne wykorzystanie tegoż zjawiska, z drugiej zaś obarczyło ludzkość odpowiedzialnością za właściwe jej wykorzystanie. Znajomość zagadnień związanych z promieniotwórczością, wpływem promieniowania na organizmy żywe oraz sposobów ochrony przed promieniowaniem może pomóc ludziom zmniejszyć zagrażające zdrowiu skutki promieniowania.

Praca $\mathrm{z}$ odpadami radioaktywnymi jest niebezpieczna i wymaga podjęcia szczególnych środków ostrożności. Wszyscy pracownicy ZUOP są zobowiązani do przestrzegania przepisów obowiązujących na terenie zakładu.

Do zadań pracodawcy należy zapewnienie pracownikom podstawowych szkoleń z zakresu bezpieczeństwa jądrowego i ochrony radiologicznej. Szkolenia te powinny obejmować informacje o zagrożeniach związanych $\mathrm{z}$ pracą $\mathrm{w}$ warunkach narażenia na promieniowanie jonizujące i stosowanych środkach ochrony oraz o znaczeniu przestrzegania odpowiednich wymagań technicznych i medycznych w tym zakresie. Ponadto pracodawca musi objąc podwładnych oceną narażenia, a także nadzorem medycznym. do:

Za pracowników jednostki odpowiada kierownik, który jest zobowiązany

- sprawdzenia, czy pracownicy posiadają ważne orzeczenia lekarskie o zdolności do pracy, w tym stwierdzające brak przeciwwskazań do pracy 
w warunkach narażenia zdrowia i życia wydane przez uprawnionego lekarza,

- zapewnienia pracownikom specjalistycznego przeszkolenia uwzględniającego specyfikę terenu kontrolowanego i planowanej pracy,

- zapewnienia niezbędnych środków ochrony indywidualnej,

- zapewnienia prowadzenia pomiaru dawek indywidualnych.

Natomiast pracownicy są zobowiązani do:

- przestrzegania zasad bezpiecznej pracy w warunkach narażenia, w tym szczegółowych przepisów obowiązujących na danym stanowisku pracy,

- współdziałania z kierownikiem jednostki w zakresie poprawy warunków pracy i właściwej kontroli otrzymanych dawek promieniowania jonizującego,

- dbałości o terminowość i kompletność wpisów w paszporcie dozymetrycznym.

Bezpieczeństwo pracy ze źródłami promieniowania jonizującego wymaga przestrzegania zasady ograniczenia czasu przebywania pracownika w zagrożonym polu, zwiększania odległości od źródła promieniowania jonizującego, ograniczenia zasięgu tego promieniowania i eliminowania skażeń promieniotwórczych, w szczególności przez:

- stosowanie wyposażenia i sprzętu zgodnie z ich przeznaczeniem oraz zaleceniami producenta,

- stosowanie środków ochrony indywidualnej,

- dopuszczanie do pracy na poszczególnych stanowiskach osób przeszkolonych i posiadających uprawnienia wymagane do pracy na tych stanowiskach,

- stałą kontrolę stosowanych procedur oraz bieżącą kontrolę i konserwację eksploatowanych urządzeń.

W przypadku przewozu materiałów niebezpiecznych należy przestrzegać umowy ADR. Jest to umowa europejska dotycząca przewozu drogowego towarów niebezpiecznych, sporządzona w Genewie 30 września 1957 r.

Przewóz drogowy towarów niebezpiecznych może odbywać się pojazdem samochodowym lub zespołem pojazdów, z wyłączeniem motocykla. Pojazd przewożący towary niebezpieczne powinien być odpowiednio przystosowany, wyposażony i oznakowany zgodnie z umową ADR. Wytyczne umowy ADR dotyczą również opakowań, kontenerów i cystern służących do przewozu towarów niebezpiecznych.

Do kierowania pojazdem przewożącym towary niebezpieczne dopuszczeni są kierowcy, którzy ukończyli specjalne kursy dokształcające, a ponadto:

- mają ukończone 21 lat,

- spełniają wymogi określone w odrębnych przepisach w stosunku do kierowców przewożących towary niebezpieczne,

- posiadają zaświadczenie ADR. 


\section{Podsumowanie}

Odpady promieniotwórcze należą do kategorii odpadów niebezpiecznych, czyli takich, które ze względu na swoje pochodzenie, skład chemiczny, biologiczny i inne właściwości stanowią zagrożenie dla zdrowia, życia ludzkiego lub środowiska. Wytwarzane są w procesach technologicznych w przemyśle, rolnictwie i przetwórstwie rolnym, gospodarce komunalnej, transporcie, służbie zdrowia itp. Odpady niebezpieczne mogą być składowane tylko i wyłącznie w specjalnie przygotowanych składowiskach lub odpowiednio zabezpieczonych częściach składowisk komunalnych.

\section{Literatura}

[1] Ustawa z dnia 29.11.2000 Prawo atomowe, art. 59, Dz.U.01.3.18 rozdz. 8.

[2] Kalda G., Savczenko Z.: Radiometria i dozymetria. Chmielnicki 2003.

[3] http://www.if.pw.edu.pl/ pluta/pl/dyd/mfj/zal03/kalinowski/www/5.html

[4] Kalda G., Shevelya V., Sokolan K.: Analiza stanu radiacyjnego środowiska terytorium Ukrainy. Nikołajewski Narodowy Uniwersytet. Prace Naukowe Nikołajewskiego Narodowego Uniwersytetu, t. 53, z. 40, 2006, s. 87-92.

[5] http://www.zuop.pl/dzialalnosc.html.

\section{RADIOACTIVE WASTES ECONOMY}

Su m mary

The paper represents the terms related to utilizing, transporting and deactivating radioactive wastes. It shows working conditions of organizations to deactivate radioactive wastes.

Keywords: utilizing, transporting, deactivating radioactive wastes 